\title{
Aesthetics of the Excavations of the Spatial Environment in Nawal al-Sadwawi's Perception: Her Novel Imra'ah Inda Nuqtat al-Sifr/ Woman at a Zero Point as a Sample
}

\author{
Dr. Hanan Bishara \\ Hahashmal St. 22, Haifa 33145, P.O.B 8349, Israel
}

\begin{abstract}
The environment of the novel is both: its Place-and-Time truth, including everything that the place includes from nature and objects, and everything that Time includes as a moving sequence or time that has its frontiers and characteristics that are connected to the age that they belong to. This means that this environment is everything that is connected to the natural medium and the morals of the characters and their lifestyles. Environment in the novel has a special concept- it is a cultural concept that is not satisfied with the total natural circumstances that surround the human being in the novel, the total social circumstances that are connected to the human being and affect his life and create the events of this life within the story.Sadawi's -The value of the Place in Nawal al ${ }^{1}$ novels is in its representation of a fundamental theme that defines the thematic frame of the novels deal with. Consequently, it is impossible to approach Nawal al-Sadawi's textual place without being pressed by its authority, which prevents this critical approach from originating from projection of the action on the texts, and makes it an exploratory operation and selection of these texts. Thus, the Places in which the major character exists and the action of the novel turn into an existence that imposes itself on the atmospheres of the text. In this way, the Place frame turns into an aesthetic pointer that justifies the dynamics of the action and achieves its process, because every event will inevitably have a Place to contain and refer to it.Ambiguity in literature is likeable due to its attraction to the reader's attention and his suspense, but if all the literary work is wrapped by ambiguity, it cannot convey its objective as it should. We can say that this is exactly what Nawal al-Sadawi applied in her novels as she had a balanced attitude regarding ambiguity, and she succeeded in it. $^{2}$
\end{abstract}

Keywords: Nawal al-Sadawi, excavations, place, time, environment, novel.

DOI: $10.7176 /$ JLLL/71-03

Publication date:August $31^{\text {st }} 2020$

\section{Introduction}

It is impossible to look at the fictional character as an isolated being depending only on its relationship with all the narrative elements or the narrative structure, and the reader should also deal with the process of character's interaction and formulation. Probably the significance of its existence requires that the objective research should realize this interaction between the character and the other elements that are probably equal in significance. However, the character's existence does not take place without its existence in environments of Place and Time.

Speaking about the anthropological function of the description of Place, Philippe Hamon (2013) says that "the described environment affects the character and motivates it to do actions, and pushes it to perform them; it is also possible to say that the description of the environment is the future of the character; he actually goes beyond that in his speech about the spatial space and its relationship with the formation of the narrative structure so that moves in harmony with the characters; he adds that the novelist should seek to make this structure harmonious with the moods and tempers of his characters and he should not include any discrepancy because it is necessary that there should be mutual influence between the character and the place in which the character lives, or the environment that surrounds it in such a way that the structure of the novelistic space will be able to reveal the emotional state that the character lives in, and even contribute to the internal changes that occur to it. Probably, the dialectic between the character and Place will certainly go towards the dialectic between Time and the character, as a result of the dialectic between Time and Place. ${ }^{3}$

In a lot of stories and novels by women writers, the description of the female characters is made within a social and psychological environment that pressed the woman in the past or presses her in the present. Thais can probably be attributed to the depth of the suffering that the woman experiences in her social environment. As for Time, it takes the form of the psychological time in the image of associations and flashbacks and dreams in order to cover the time stages within the novel, and so that the present moment will carry the largest amount of passion and suffering in the character's life.

Several women writers agree in their outlook about the past time and their attempt to condemn it in the

\footnotetext{
${ }^{1}$ Bachelard, Gaston (1980) The Poetics of Space. Translated as Jamaliyat al-Makan by Ghaleb Halsa. Bagdad: Dar al-Jahiz, p. 83.

${ }^{2}$ Al-Sharoni, Yosuf (1986). Rihlati Ma' al-Riwaya. Cairo: Dar al-Ma'aref. pp. 88-89.

${ }^{3}$ Hamon, Phillippe (2013). Simyulogiat al-Shakhsiyat al-Riwa'iyya. Translated by Sa'id Benkrad. $8^{\text {th }}$. Ed. Latakia. Dar al-Hiwar li al-Nashr wa al-Tawzi'. P. 54.
} 
character's environment.looks for the roots of suffering in the character's life which This historical excavation, ${ }^{1}$ is found in the novel under discussion - in Nawal al-Sadawi's novel: Imra'ah Inda Nuqtata al-Sifr. Al-Sadawi's exposes the sequence of the events of the novel and her excavations of the roots of the problem of the main character, Fardous, which makes her at the end refuse life and her living in it. This led her to the 'zero point', where there is no fear of death, no desire for anything and freedom from everything. "I desire nothing, I have no hope for anything, and I fear nothing. I own my freedom. Nothing enslaves us in life except our desires, hopes and fears."

Dealing with social circumstances requires social awareness that absorbs the total relationships that connect the human being with his society, depending on the social causes that produce these relationships. The more the writer's social awareness increases, the more his works are filled with sincerity of affiliation with the environment, which is likely to push him to create his artistic characters from the depth of his environment, and from the furnace of their social relationships in the frame of Time and Place. Then, the writer introduces artistic works in which the characters move truthfully and freely.

Place is one of the elements of the environment that glitters within the story, and the more real the place is, the more it makes us remember the places we lived in or dreamed to live in. Place should not be a description of a condition that the characters go through such as poverty, richness. It should not also be an arena for the current events that are taking place or an indication of persons and their class position or lifestyle. ${ }^{3}$

In my view, Nawal al-Sadawi succeeded in achieving that as she showed social awareness through which she reflected several relationships that connect the heroine of the novel with her surrounding society.

\section{The Study}

The narrator in the novel Woman at a Zero Point ${ }^{4}$ describes the environment in which Fardous lives in the countryside in a poor house, in which she moves unwillingly. In summer, she takes the corner of the oven, and in winter, she stays in a very cold place: "Our house was cold and my father would move my mattress and cushion in winter to the cold sea-hall, and take my place in the oven-hall. In summer, I would find my mattress and cushion in the oven-hall."Then, the narrator describes Fardous's movement to the city with her uncle. There, a great 5 change takes place in her life, and throws her to abyss.

The character's place environment and the human environment reveal some of her aspects and traits. As said before, Fardous in Woman at Zero Point does not own anything of the house she lives in except a mattress and a cushion, "Our house was cold and my father would move my mattress and cushion to the cold sea hall... and in summer, I would find my mattress and cushion in the oven hall." 6 This description points out her poverty and her caste, her bad economic condition, and her social isolated condition. Her life is limited in its landmarks and does not go beyond the borders of her house, field, the water-wheel, and the canal. However, despite her severe poverty, she was satisfied and content: "I used to prefer the field to the house. I used to play with the goats and ride the water wheel and float in the canal with the boys. The novel describes the abject poverty of Fardous' family. The ${ }^{7}$ mother is compelled to hide the food from her children for her husband: "My mother used to hide his food from us in an opening in the oven." 8

As for the place of the natural environment, it does not construct the character or its traits, but points them out and reinforces them. The natural scene and natural environment in the novel refer to a parallel similar relationship. The street into which Fardous escaped from the house of Sheikh Mahmoud is "full of walking people or riding people on buses; all of them are in a hurry, running without seeing one another. Those who are walking wear ragged clothes; the heels of their shoes are worn; their faces are pale; their eyes are withered; burdened with worries; resigned to something like sadness" that is parallel with Fardous's lost sad wandering soul. 9

In another place, after Fardous's escape from Bayoumi's house, the description of the street is parallel with her condition, and prepares for another life that seems, at first, to be a clean life because she will live, at least, in a clean house in its form with Sharifa Salah al-Din: "I found myself in a street that I do not know, a clean paved street, but without asphalt, a street that overlooks the Nile, surrounded by high trees, and the houses are surrounded by walls and green gardens; the air entered my chest clean and without dust."10

The human environment in which Fardous moves consists of men who look for sex at brothels. They include rich and poor men who suffer from uncertainty and duplicity in their life; they suffer from separation and alienation

\footnotetext{
${ }^{1}$ Rasheed, Amina (2013).Tashazzi al-Zaman fi al-Riwaya al-Haditha. Cairo: al-Hay'a al-Misriya al-'Amma li al-Kitab. P. 73.

2 al-Sadawi, Nawal (1979). Imra'ah 'Inda Nuqtat al-Sifr. Beirut. Dar al-Adab. P. 111.

${ }^{3}$ Al-Nabulsi, Shaker (1994). Jamaliyyat al-Makan fi al-Riwaya al-'Arabiyya. Beirut: al-Mu'asasa al-Arabiya li al-Dirasat wa al-Nashr. P. 55.

${ }^{4}$ Al-Sadawi, Nawal (1979). Imra'ah 'Inda Nuqtat al-Sifr, p. 21

${ }^{5}$ Ibid., P. 21

${ }^{6}$ Ibid.,p.22.

${ }^{7}$ Ibid., p. 17

${ }^{8}$ Ibid., p. 23

${ }^{9}$ Ibid., p. 47.

${ }^{10}$ Ibid., p. 59
} 
between what they say and what they do. They leave their wives and go to look for prostitutes. Actually, they are merely a negative, hopeless group of people in crisis, who betray the values and human legitimacy; a group of men who betray their wives and disconnect from themselves.

The change of place in the novel of $A$ Woman at a Zero Point plays a central role in escalating the narrative path. Fardous's movement from the village to the city, the place of her uncle's study and education represents two temporal moments: the moment of the Uncle's leaking of 'awareness' to Fardous, and the moment of her possession of her awareness by herself, that are framed in an artistic way. This movement, as a symbolic indication, embodies a place-transformation that foretells the beginning of a preliminary achievement in Fardous's path towards freedom and her emancipation from the male patriarchal authority, starting with her father and then with her Uncle.

However, the period of Fardous's movement to the city and the beginning of her learning at school was not able to be a helping active factor for her as she was looking forward to having a shining future, free of the male patriarchal authority, which suppresses the possibility of movement of the intellect. Thus, Fardous looks like a person who is unable to achieve the action of transformation (walking ahead and liberation) by asserting her identity and humanity, because she remained without the elements that enable her to fulfill the action of 'achievement'. She wants to make progress by education but remains without the elements of 'knowledge' and 'ability' (knowledge of action), which makes her a hero who is unqualified to practice the decisive moment.

The place in the character's psychological and emotional dimensions is confirmed when it deals with the concepts that are connected to the place. In the novel of Woman at a Zero Point, for example, Nawal al-Sadawi deals with compelling social circumstances, with a woman who has been oppressed by time since her childhood. Her life enters many swirls and hard fluctuations that lead her ultimately to seek shelter in the world of prostitution from its wide doors. However, the place that constituted the scene of events of the novel was actually connected directly with everything that Fardous went through from the beginning of the novel till its end when she kills Marzuq.

Yousef Even argues that many writers confirm that environment affects man's temper and explains and accounts for his future behavior. They also maintain that there is a relationship between man and his environment and the street that he lives on, and between man and his city and country. The life of the individual is defined by the form and image of his home and the social climate that prevails in his environment and place of work, his city and country ${ }^{1}$. In Woman at a Zero Point, all the elements that Yousef Even speaks about affect the central character. The beginning of her life in the rural countryside, where ignorance and poverty make Fardous live a life of poverty and deprivation, which Fardous expresses and talks about in a lot of situations in the novel.

This study locates a lot of vocabulary that is related to place environment in the novel, which, as a whole, constitute a body of knowledge of the environment that surrounds the character, which the writer embodies successfully in a psychological pressuring frame, which increases every time Fardous has experiences of pain that she repeatedly had. Thus, her feeling of ordinary time vanishes and it is substituted by the psychological place, casting its shadows on the other environments: "I did not know such a pain in my life. When I was a prostitute, may pain was less acute. An imaginary pain... probably because when I was a prostitute, I was over-insulted. There was nothing there that can insult me more. Or, maybe the life of the prostitute is the street and there is nothing that I can expect from the street, but in love, I expected something." ${ }^{2}$

Environment in the novel is a human, mythological social and sociological reality that is woven into the creation and formation of the characters: the cruel father, the naïve mother, Fardous, the contradictory uncle, the miserly husband, Bayumi the Beast, Ibrahim the Fake, Marzouq the Pander, Sharifa Salah the Procurer. Each of these characters is depicted in a visionary artistic way.

When the creative writer creates an artistic model in which he reveals its internal world, and analyzes its content and shows its relationship and interactions, he divides it and objectifies it in order to reach its internal Self, to the 'I', the individual ego and its connections with the social motives in order to uncover them. This is what Nawal al-Sadawi does in her novel Woman at a Zero Point. She divided Farous's character and makes it something. She put it under discussion and self-debate in order to lead us ultimately, through stopping at every station in her life, to exploration of that Self, and discovery of the motives that pushed it to do what it did. It seems that, with doing this, we are re-exploring Fardous's character in order to reach the heroine's journey of life, and through place-stations that are related to her life, reach the Self and hidden points of the human soul.

The environment that al-Sadawi depicted helped to do that, starting with Fardous's life in the countryside, where the peeping eyes are: "they look around with peeping suspicious aggressive eyes in a humiliating way" 3 and ending with the city, where the eyes follow her and she feels very scared: "I saw just eyes that move towards me very slowly, and slowly I saw them fall over my shoes and rise very slowly above my leg, my thigh, my abdomen... then they finally settle in my eyes." 4

\footnotetext{
${ }^{1}$ Even, Yosef (1980). Hadmot bi Siporet. Tel Aviv: Sifriyat Poalim. P.92- 96.

${ }^{2}$ Al-Sadawi, Nawal (1979), p. 95

${ }^{3}$ Ibid., p. 17

${ }^{4}$ Ibid., p. 48
} 
To sum up, the place environment assumes an oppressive social, geographical entity on the character in the novel of $A$ Woman at a Zero Point, as it robs Fardous of her freedom after she imagined she had got it just because she became a prostitute. In this way, Nawal al-Sadawi wove her novel in a narrative harmonious linguistic structure. The psychological features in A Woman at Zero Point prevail over the social environment. Fardous is smashed by pain and oppression, which is described in such an accurate way that omitted the realistic social element of the character, and consequently, the environmental elements retreated.

This structure of the story reveals features of a lofty environment in its presence, and social and psychological influence on Fardous's character. Fardous plays a major role in revealing those contradictory features in the structure of the novel. She starts her life in the countryside and then she moves to Cairo with her uncle, who learns at al-Azhar. After that, she starts moving from one place to the other, starting with the boarding school, then to her uncle's house after he gets married, and then to the house of Sheikh Mahmoud after she marries him. Then she moves to Bayumi's house after she escapes from her home, then to Sharifa's house, and finally to her own house, and the last station was the prison cell after she kills Marzuq, the pimp. Fardous roams in the streets and neighborhoods between people and contradictory places in the city map, besides her confrontation that never stops with herself between the past and the present. Her psychological environment mixed with the city, its streets and people.

Description of the female characters is made in many stories within a social and psychological environment that pressures the woman, whether in the past or the present. This is probably due to the depth of the social suffering that the woman experiences in her social environment. Several writers meet in their outlook at the past and their attempt to condemn it in the environment of the character. This historical search and excavation in that looks for the roots of suffering in the life of the character exists in the novel under discussion. In her exposition of the events of the novel, Al-Sadawi excavates the roots of Fardous's problem and that excavation made her ultimately refuse to continue her life with her husband Sheikh Mahmoud and that led her to her liberation from everything: "Once, he hit me with his thick stick so much that blood started flow from my nose and ear; I left his house and did not go to my Uncle's house. I walked in the street... the street was wide... and I am a piece of stone that was thrown into it..."1

\subsection{Place and Formation of Nawal al-Sadawi's Vision in her Novel: Woman at a Zero Point}

'Place' is where people live; place is the people who grant it its characteristics and indications: they lend it its nature and it grants them characteristics that they would not get if they were outside $i^{2}$ Place dies when the close relationship that connects man to it dies. Sense of place is considered an original and deep feeling in the human conscience, especially if the place is the homeland of familiarity and affiliation, which represents the placental connection in the womb of mother/ Earth, and is connected to the bliss of childhood and desire of youth. ${ }^{3}$

Sense of place for the writer is like one's 'sense of time' from the perspective of his influence by the prevailing look at the woman, which is likely to imprison the woman/ self/ writer in a series of physical and spiritual realities, and stands in the face of her pursuit to communicate freely with the outside world and the others as an obstacle.

The attempts of the heroines to penetrate those circles remain captives to counter-attempts by them in order to protect themselves from the outside. These attempts are represented in the circle of the self, which appears not only through the first-person narrator but through the woman's dominance (as a central character) on other characters such as the 'man' for example. Al-Sadawi's embodiment of this experience appears through the tension of movement and the implied dialectic relationships between the aerial and terrestrial, the inside and outside, or the closed and the open, because the role of the dialectic movement is always to reflect the condition of division that the Self suffers from in its tense movement between the experience of 'familiarity' (inside) and the experience of escape towards the outside (the abstract and the infinite).

The role of the spatial image in al-Sadawi's novels lies in its bearing of features that are antagonistic to the main character. As place is considered 'people', the place here embodies the image of the ordinary father's attitude towards his daughter, Fardous, in all its cruelty and his ability to cause his daughter's loss. The value of the spatial image here lies in its reflection to the image of 'loneliness' with the prevailing social values that are hostile to the woman. Therefore, Place appears to be positive in its effect on the structure of the formation of the narrative character, as we find that the value of Place moves through the collective unconsciousness to its residents, and affects, not only their thoughts but their movement and actions. Whether this place is a village or a neighborhood or a city, it has its special ideology that controls its residents by its representation of the highest psychological or intellectual level, besides the linguistic level. Therefore, we find that the characters speak in the language of their place, in the colloquial language, the rural language, or the city language, as long as the characters represent the real extension of Place.

The writer's sense of place in al-Sadawi's works is influenced by her relationship with the other (the man),

\footnotetext{
${ }^{1}$ Ibid., p, 52-53.

${ }^{2}$ Abd al-Hamid, Shaker (1988). Dirasa Nafsiya Topologiya. Majallat al-Qahira, Issue 85, p. 65.

${ }^{3}$ Othman, Itidal (1988). Idha'at al-Nass. Lebanon: Dar al-Hadatha. p. 6.
} 
and this is embodied in an image of alienation. There is no affinity with the place if the Self is alienated from the Place in the case of static and negative relationship with the 'Other'. The Place, whether it is a desert or a coast or a village or a city, is colored in its description by the dialectic of its relationship with the 'Other/ the Man'. We find that it turns from a familiar loveable place into a hated hostile one if the relationship with the Other/ the Man is torn, where it reformulates itself through adoption of the same feelings in a way that serves the character.

At the same time, it deeply affects the development of the event and its formation. This can be illustrated by the gloomy and terrible image of the place that we see in A Woman at Zero Point, where we see the coldness of the cell, where Fardous is, carrying the image of the self with all her suffering and despair in her relationship with others, waiting for the judgment of execution: "This woman is a real one of flesh and blood; I met her at al-Qanater prison a few years ago... she is not like those murderers who stay here; she is completely different... she refuses to meet anyone... she rarely eats and does not sleep except at dawn". ${ }^{1}$

Fardous's words "Can the Nile and heaven and trees change? But I changed, so why does the Nile not change? Why don't the color of trees change?"rebel against the traditions reflect the condition of the Self and its desire to ${ }^{2}$ because of her refusal to them and their injustice to her. At the same time, her speech foretells the condition of conflict that it suffers from, and the confusion and mixture of her future events that will result, because "the extremely old thing inside us is connected to a kind of extension of existence that life curbs, and reeks of caution, but it initiates its action when we are alone. The moment we stay motionless, we live in another place, dreaming of a wide world. The extremely old thing is the motion of the motionless human being. It is one of the dynamic features of static daydreaming." 3

While the female Self seems to be in the position of motionlessness, the Other/the Man appears to be in the position of motion. We see him invade her loneliness, enter it, and leave it without any justified logical reason by the writer. The act of 'motion' here reflects the man's position from the point of view of the heroine. That appears through his possession of the authority of action (motion) versus her waiting for his motion and action. This can be illustrated by the following event in $A$ Woman at Zero Point: "One day, while I was sitting, one of the employees saw me.. he said from afar and before he came close to me: Who? Who is sitting there? And I said: It's me, I am Fardous, and he came close to me and recognized me and was surprised... he sat with me. His name was Ibrahim". ${ }^{2}$

As far as the place embodies the psychological composition of the characters in al-Sadawi's novels, it foretells the expected events in such a way that, ultimately, the novel perspective/ the writing Self and the reality of its vision to the world becomes clear and in harmony with the prevailing ideology in society. In Woman at a Zero Point, Nawal al-Sadawi is not satisfied with just describing the rural nature of mentioning the traditions and customs in the village, but we see that she is interested in describing the spirit of the climate "as a repeated place" due to the customs and traditions that are likely to suppress the soul and body: "I belong to the lowest class by birth of an illiterate poor farmer, who did not know anything about life except cultivating the land and selling the poisoned buffalo before it dies... stealing the yields of his neighbor, and hitting his wife every day till she kneels on the ground. The morning of every Friday, he wears a clean smock and goes to pray Friday prayers... and I see him after the prayers walking among men of his likes.

At times, I could not recognize my father among them. I asked my mother about my father and how she gave birth to me... she beat me and brought another woman with a razor and cut a piece of flesh from between my thighs". ${ }^{5}$ Thus, the countryside changes from a beautiful green land into a "repeated place" through the actions of the people who imprison and murder the Self and thought and motion in the spatial frame, which negatively affect in silencing the element of motion within the self, the body and thought. If the narrow place (room, or private room) changes into a "repeated place", this is due to the nature of its relationship with the world, which is reflected on the place. The place changes into a friendly "familiar place" according to the fulfillment of a calm relationship with the other. This is does not happens to the heroines of Nawal al-Sadawi. No harmony or familiarity took place with any of them with the place as a result of disharmony with the other/the man. Besides, the cell (where Fardous was imprisoned) and all its associations with all the maneuvers of the underground world, suggest shutting oneself inside walls such as clocked isolation cells.

The reader notices that there is a clear feature in Nawal al-Sadawi's works, which is the dialectic between the internal and external. This feature reflects al-Sadawi's rebellion against the internal place because she considers the 'place' responsible for her personal crisis with the Self and the Other. As long as the 'prevailing values' in society have a role in the formation of the Arab mentality, the place also has a fundamental role in defining this mentality, from which these values originate, including the customs and traditions that are likely to limit the woman's movement and freedom in society. In general, place in the sense of the writing Self appears to be antagonistic to the Self. The value of the symbolic image of place lies in its embodiment of the siege of the Self in

\footnotetext{
${ }^{1}$ Al-Sadawi, Nawal (1979), p. 5

${ }^{2}$ Ibid., p. 63.

${ }^{3}$ Bachelard, Gaston (1980), The Poetics of Space, p. 171.

${ }^{4}$ Al-Sadawi, Nawal (1979), p. 86-87.

${ }^{5}$ Ibid., p. 16-17.
} 
its relationship with the Other and the external world.

For example, the symbolism of circles embodies the introversion and withdrawal of the human being within the place and vital circumvention of the Self ${ }^{1}$. The writer's embodiment of place does not take place just through motion, but description also has a role, as we see it accompanying the feelings of the character and reflects it. Besides, it deals with the details of actions and events in order to embody the truth of things in their stability and freedom, too.

Nawal al-Sadawi succeeds in her novels in describing the reality in which the main character lives. Time and Place, within which the characters and events take place, define the dimensions of characters and tell the reader about the continuous severe conflict that takes place between the classical and the modern that is represented by consecutive generations. Al-Sadawi clearly registers the thoughts of every stage and every generation. The features of conflict, and the thoughts and hopes and pains of the new generations become clear through this indirect registration. Al-Sadawi deals with a lot of minor characters in her novels in attempt to define the identity of absolute time and place

The relationship of the character with the place is based on reciprocity and integration, "because each of them digs in the other shallow or deep impacts. Place excavations in the character take biological, psychological and social levels, and the siege of place and time to their resident increases so much that the human being adopts the image of his place, and his behavior becomes a translation of the behavior of the place and his language becomes the language of the place". ${ }^{2}$ These excavations become clear when the characters get a place shock and get feelings of profound malaise and introversion, which are basically spatial feelings that were engraved on the behavior of the character. Thus, they got wrapped with that narrowness and siege which made their action, at the end, the best expression about that. Nawal al-Sadawi is not far from that as this excavation is prominent in some of her female characters through their psychological feelings and interior monologue on which place has its deep impact.

The central characters in Nawal al-Sadawi's novels are often dominated by a compassionate nature, which reflects the character's return to its Self, especially the female character. This can be recognized in one of the prominent features in her novels. When the female character shuts the door of her room, she feels that the place is closed on her, and she suddenly feels that she is hit by introversion, which is an emotional feeling that indicates the rooted relationship of the character with the place. This can be illustrated by the following quotation from the novel: "A real woman of flesh and blood is sitting on the floor in front of me, and the cell's window is closed, and the door is shut." ${ }^{3}$ Besides, Fardous's character in the novel is nothing but another reflection to the philosophy of the confined space; the major character lived the space siege, and psychological introversion in place through those events, through which the moment of relief has passed through, after Fardous's discovery of the entity of her freedom, and Bdour's discovery of her suppressed will, and her constant search of her stolen freedom.

Fradous says after her liberation from Marzuq by killing him: "And I opened the door and went out to the street. My body was as light as a feather as if the weight of my body was nothing but accumulation of fear over my body...I did not want anything nor hope in anything and was not afraid of anything as I own my freedom."4

With the exacerbation of the feeling of the Self by its siege in Nawal al-Sadawi's novel, we find that the main character always seeks exit, but it is surprised to find all the doors tightly locked in front of her, either by the father or uncle or husband or the pander, as it happened to Fardous, and despite this act of exit, which includes in itself implied rebellion against the man, the Self remains suffering alone in one place. The exit or movement outside the place becomes an alternative adventure of the experience, which bears the meaning of taking risk within itself. The movement/exit also has its important implications that are derived from the myth of a quest. The implications of exit constitute the desire for change of reality- spatially, temporally, and culturally. Exit includes inside it a desire for transition from the old to the new in the spatial, temporal, and cultural meaning. Exit also includes by itself a desire for escape from time and place.

To sum up, all the forms of rebellion and exit imply isolation from time and place. The forms of rebellion and refusal include within themselves a desire for change in all its forms, including time and place. Movement in place contributes to the general definition of the vision of the ideology and tendencies of the main character/ the writing Self. The writer uses them artistically to move with them from the space of consciousness to the unconsciousness. Here, the place or the act of movement within place appears to have a new feature, which is the contribution to the crystallization of the character's awareness of itself and of the Other. Therefore, Fardous gets out of the house of Sheikh Mahmoud to the street as a sign of her definite ideology and tendencies. However, introversion into one place without being able to perform any movement implies one's helplessness and inability to function or interact with the external world, namely, the others, as a result of strict oppression and loss of unity and affinity with others.lives internally. Her feeling of being Spatial introversion represents one of the features that the character ${ }^{5}$

\footnotetext{
${ }^{1}$ Bachelard, Gaston (1980), The Poetics of Space. P. 9, 12

${ }^{2}$ Hussein, Khaled Hussein (2000). Shi'riyat al-Makan fi al-Riwaya al-Jadida. Riyadh: Mu'sasat al-Yaman. P. 104

${ }^{3}$ Al-Sadawi, Nawal (1979), P. 14

${ }^{4}$ Ibid., p. 106.

${ }^{5}$ Qassim, Siza (1984). Bina' al-Riwaya. Cairo: al-Hay'ah al-Missriya al-Amma li al-Kitab. P. 77.
} 
shut in indicates her return to the Self. Spatial introversion for some researchers is considered a kind of "suppression of the femininity of the female and her deprivation from going out openly."1

We find that the change of place in the woman's novel is intangible in comparison with the change that happens to people as a result of change in time. The woman's character is in constant development under the impact of time, but she is isolated within her society. Despite her going out of the shell of the house in order to study and work and communicate with the external world, she is still living in spatial isolation of spiritual and physical shells that hinder her pursuit of communication with the world and others. However, and in order to protect herself, she uses the circle of entity.

We find her live within her body, and then within the circle of her house, and then within the circle of the city, the region, the state, and the whole world. At the same time, she lives another sequence of isolating circles that are represented in herself, her family, her sex, her homeland, and humanity. For example, in Woman at a Zero Point, Fardous lives in isolation within her environment, her city and her family, but her attempts to break the tightness of this isolation are varied; Fardous refuses to be like other women: "I felt that I was not like women or girls... what concern girls did not concern me". ${ }^{2}$ Despite the freedom that Fardous enjoyed in Woman at a Zero Point, after she entered the world of prostitution, and everything that emerged from her take-off into society, she lived in a real isolation that stemmed from her attempt to protect herself. Thus, we see her living within shells that are linked with each other, despite their external appearance that suggests their connection and unity with all these groups, and their breakthrough of all borders.

Nawal a-Sadawi's heroine declares her alienation by rebellion or refusal to society, or by traveling, and since Place is People, as has been said before, rebellion against place is an extension to rebellion against human beings, specifically the man, being the real representative of the Superego / Super authority of the place, which is likely to limit her freedom and movement.

Therefore, the heroines' rebellion and refusal of Place is expressed through their rebellion against him or excluding him. However, his exclusion from the place appears through his exclusion from participation in management of the event or performing it in the story due to the domination of the writer's Self on the movements of the events in the story, and, at the same time, man's exclusion from them.

Man's exclusion from real participation in developing the events of al-Sadawi's novels is considered an implied introduction that embodies her desire to exclude him from reality or, at least, excludes his authority over her, in real life. It also embodies the movement of the woman's/ heroine's/ writing-self and emphasizes her authority over the Place, even if through her declared open movement.

Since frustration is the inevitable fate that every female experience with the "other" reaches, the 'dream' is the final and only resort that bears the Other and the Place simultaneously. The man in reality is given names and nicknames that suit the wide distance that exist between them such as "the stranger", "the old man", "the elderly man", "the big man", and the absent remote man". In this repeated reality in al-Sadawi's novels, the ugliness of place accompanies the ugliness of the husband as we see in Woman at Zero Point. For example, the marital home of Sheikh Mahmoud means nothing except a comfortable bed besides cleaning, humiliation, and extreme parsimony of the husband: "I moved from my uncle's house to Sheikh Mahmoud's house, and thus, I had a comfortable bed instead of a wooden couch; a bed that I did not lie on to have some rest from the hard work in the kitchen, and cleaning the big house and large furniture...once he found in the garbage bin some remnants of food and screaming so loudly that the neighbors heard him. Then he started beating me for no reason." 3

Nawal al-Sadawi employs the element of Place in the service of the dramatic situation in a way that contributes to the formation of the issue which each novel deals with, individually. In my view, this employment serves to weave the connecting thread of the contents of the novel. For example, al-Sadawi employed the prison cell (place) in order to serve the dramatic situation, and thus, it contributed to the formation of the structure of 'failure' that the heroine/ Fardous felt, which, in my opinion, is the weaving thread of the content of the novel; "I do not want anything, and hope for nothing, and do not fear anything... my freedom fills them with anger; they want to enslave me through a desire that I have or something that I fear... I am nothing but a one woman... no matter who I was, I was nothing but a successful prostitute..."4

These contexts and many others in the novel of the study clarify the psychological state of al-Sadawi's heroine, who is full of feelings of frustration and crisis, and confinement of the Self and its decline. The heroine got fed up with what happened to her and was filled with fear. Based on this, we notice that the dramatic line in al-Sadwai's novels was connected to the social background of the heroine and her daily life. Probably, Nawal al-Sadwai was extremely cruel to her heroine as she made her fight society individually and alone, as if, by this, she was opening a certain line that had a great effect on the novel - the line of conflict between the resentful character of society and its challenges that are represented in the obstacles that are set in front of every person who tried to break its

\footnotetext{
${ }^{1}$ Salah, Saleh (2003). Sard al-Akher 'Abr al-Lugha al-Sardiya. Beirut: al-Matkaz al-Thaqafi al-'Arabi p. 142.

2 Al-Sadawi, Nawal (1979), p. 30

${ }^{3}$ Ibid., p.49-50.

${ }^{4}$ Al-Sadawi, Nawal (1979), p. 111-112.
} 
rules like Fardous.

Probably, this is the cause of the heroine's tragedy and her downfall at the end of the novel. Social pressure from outside and psychological pressure from inside interacted and the heroine, any heroine, has no choice but to surrender to the two pressures that made her lose her balance and ability to accept her society. Hence, the general form of the novel is formulated according to the conflict that is taking place between the heroine and her society. Besides, it is noticed that Nawal al-Sadawi made use of the main elements of the Place in the novel so that all of them would contribute to the creation of the heroine's tragedy, and ultimately, lead her to her inevitable fate, death. In Woman at Zero Point, the cell was in the prison.

In my opinion, Nawal al-Sadawi is not concerned with description of the place as much as she is concerned with the reality that the place conveys to the reader. Besides, she is not concerned with mentioning the names of places as much as she is concerned with the description of the environment and the psychological atmosphere that it reflects. The character moves and the events move with the time that moves, too, while place remains in fixed, and does not accompany the person and his decline and old age that happen to him under the effect of time.

In Woman at a Zero Point, Fardous says in her description of the cell: "There was no bed or a chair or anything to sit on,"and about the house where she was born, Fardous says: "Our house was cold, and my father was ${ }^{1}$ moving my cushion and mattress in winter to the cold sea-hall and taking my place in the oven-hall."

\subsection{Dialectic of the Space of the House in the Novel of Woman at a Zero Point}

'Home' occupies an important space in man's life. It is his shelter after a day of hard work. Home is considered a stable spatial value that allows approaching it from the internal angle as a geometric space that refers to specifications of stability, intimacy, warmth and safety because it represents "our first corner in the world, and as it has been repeatedly said 'our first being'. It is a real being in every sense of the word"'.

'Home' is associated in one's life with a lot of significant memories that contribute to the formation of his character, and this depends on the size of the house and the people who live in it.Besides, the kind of furniture, ${ }^{4}$ the number of pieces in it, the manner in which they are distributed and arranged in the rooms is considered an indicator that reveals the nature of the character, its social level and degree of its awareness and education. ${ }^{5}$

The total survey of the place in Woman at a Zero Point reveals different forms of places that can be defined as: the personal place (home, room), and the collective place (street). Among the rhetoric substitutions that place takes in al-Sadwai's novels is that it enables us to approach it from another place that is defined through the duality of internal/external that is achieved through the topography of the house, being an individual closed place that is parallel with the street, being a collective place that is open onto the 'other.' The space of houses occupied a significant position in al-Sadawi's novels, and it took three forms, whose indicative function differs from other forms $^{6}$, which are: the family house, the marital house and the independent house.

\subsection{Space of the Family House}

The space of the house for the woman/ the main character turns in al-Sadawi's novels into a small homeland, in which the she practices her daily rites and imagined dreams because the house, according to the texture of values that it represents should include the individual and secure his/her existence in it.

The family home represents a space where the female does not feel familiar or intimate; she actually feels disharmonious with it. She feels depressed, bored, and empty and falls into a psychological stress. As a result, a desire is born in the woman to rebel and revolt against the prevailing conditions, mentalities and patterns of behavior and outlook at the world. This can be illustrated by Fardous's feelings about her home in Woman at a Zero Point: "Our house was cold". ${ }^{7}$ This is a house in which the father deals with it and its inhabitants as he likes: "My father used to move my mattress and pillow in winter to the cold sea-hall and take my place in the oven-hall. In summer, I used to find my mattress and pillow in the oven-hall". ${ }^{8}$ The words "our hall" in the sentence "our house was cold"9 integration between the character with the place and her openness onto the 'Other' and 'life', which constitutes a presence of the senses that are connected to the psychological condition of the character, who kept this matter in memory and did not forget it at all.

\footnotetext{
${ }^{1}$ Ibid., p. 13

${ }^{2}$ Ibid., p. 21

${ }^{3}$ Bachelard, Gaston (1980), p. 36

${ }^{4}$ Shaheen, Asma (2001). Jamaliyat al-Makan fi Riwayat Jabra Ibrahim Jabra. Beirut: al-Mu'asasa al-Arabiya. P. 31.

${ }^{5}$ Butor, Michel (1969). Essaies Sur Le Rpman, Paris: Gallimard. PP.59-72.

${ }^{6}$ The 'house' is more a narrative space than a geometric shape, walls and furniture. It is an indicative field that establishes a number of dimensions, symbolic levels that are connected to the conscious and unconscious human existence, and his memory through the dialectic of the existing past, where places always have their history whether towards the universal history or personal history. Any movement of place will mean change in the time structure and moderation in memories and projects. For more information, see: Bahrawi, Hussein (1990). Bunyat al-Shakl al-Riwa'i. Beirut: al-Markaz al-Thaqafi al-'Arabi. P. 14. 43; Bachelard, Jamaliyat al-Makan, p. 58.

${ }^{7}$ Al-Sadawi, Nawal (1979), p. 21.

${ }^{8}$ Ibid., p. 22

${ }^{9}$ Ibid., p. 20
} 
Probably, the main reason that makes the character remember this place and keep it in its silent image is her psychological feeling about the eternity of place and impossibility of changing it. However, in another place in the novel, Fardous shows the extent of alienation that she lives in and feels in that house: "I would enter my father's home and look at the clay walls as a stranger one who has not entered it before. I would look around me as if surprisingly, and as if I was not born in here, but as someone who has fallen suddenly from heaven, or has just rose up from the bottom of the earth only to find myself at a place which is not my place, and a house which is not my house, and a father who is not my father, and a mother who is not my mother." 1

Fardous's house in the novel Woman at a Zero Point reflects her features and characteristics in her childhood: simplicity and naivety. The narrator points out simple things that concern Fardous in her father's house, which are 'her mattress and her pillow" :"Our house was cold, and my father used to move them..."2 After she moved to live in her uncle's house, her things were also simple. There was a wooden sofa in the dining room: "In that house, there was no place for me except the sofa. It is a small wooden sofa in the dining room." 3

At the family home, we find disagreements between mothers and fathers on different issues such as: the daughter's fate, as we see in Fardous's words in Woman at a Zero Point: "I knew that I moved to my uncle's home... and that I have no place for me in it except the 'sofa' ... and the uncle's wife says: but what will you do with her now? I have a great idea ... my uncle Mahmoud is a good man... and he is alone... if Sheikh Mahmoud marries Fardous, she will live with him... Fardous has grown up and she must get married.Then, this house is associated ${ }^{4}$ with the burden of the inherited traditions, customs and norms that represent shackles that prevent the woman from practicing her freedom and express herself in a reality the changes and develops, which creates tension in the relations between the daughter and her mother due to the difference between their cultural levels and outlook about life, in which the scientific thought and superstitious supernatural thought contradict. This is confirmed by the scene of Fardous's circumcision, which took place by the initiative of the mother just because Fardous asked about her father and how her mother gave birth to her without a father: "and I asked my mother about my father and how she gave birth to me without a father. She beat me and brought another woman with a knife or a razor and cut a piece of flesh from between my hips. ${ }^{5}$

The patriarchal authority of the father is consecrated in the family house to represent the type which limits the choices of the daughter and her perceptions in creating her entity and practice of her life. All that makes the female introvert within a space that is narrower than her house, which is the space of the room that gives her some freedom of movement, thought and dream, which are forms of intimacy that she practices with herself.

This narrow place of the house, in which the female finds herself, is the prison in which the fundamental taboos that control people's mentalities and souls put the woman in. It is the prison of the body/ the shameful nakedness (awra) that should be concealed. This explains why the women novelists conceal the details of the house and their silence about its taboos. Actually, they conceal the details of the body and keep silent about it. All that compels the female to leave that space/ prison due to the circumstances. She leaves for other spaces where she finds an outlet such as the street, work, university or other countries, but ultimately, she returns to it and shuts herself in the circle, where she moves from it to the marital house of the independent house. The Family House also represents a space that is wrapped by inactivity and depression and complete silence, as if it were a grave that includes a female, and that is confirmed by Fardous. The reader notices that such houses do not secure settlement and familiarity for the main character / the woman. They hardly secure the possibility of the female's inclusion. Therefore, Fardous says: "Our house was cold..."6 and implies that there is no warmth, no love nor intimacy in the house.

\subsection{The Marital House}

The reader notices in Nawal al-Sadawi's novels that if the relationship of the woman at the beginning of marriage becomes familiar, dissonance will soon replace familiarity as the space of the house soon turns into a prison that is narrower than the prison of the Family House. This space soon becomes a source of stress, resentment and tension due to the arguments and disputes between the wife and the husband. That generally happens after she discovers that there is a fracture in her relationship with him, which is his infidelity. Her suffering rises after the assassination of the dream of the female and the breakdown of her dignity. This is embodied in Fardous's experience and her mother in Woman at a Zero Point.

In Woman at a Zero Point, the narrator describes the failure of the mother's experience with her husband, who beats her for trivial reasons before dinner: "I belong to the low class by birth of a poor father, who beats his

\footnotetext{
Ibid., p. 21

${ }^{2}$ Ibid., p. 21.

${ }^{3}$ Ibid., p. 41.

${ }^{4}$ Ibid., p. 40-42

${ }^{5}$ Ibid., p. 17.

${ }^{6}$ Ibid., p. 21
} 
wife every night till she bites the ground."represents suffering in the house of Sheikh Mahmoud ${ }^{\text {Fardous's experience } 1}$ of a different type. She gets married to a niggardly old man who narrows life down on her through his niggardliness and mistreatment. His house becomes a narrow space where the woman finds no settlement and rest. Fardous says: "I moved from my uncle's house to the house of Sheikh Mahmoud, and thus, I had a comfortable bed instead of the wooden sofa; a bed which I would not lie on to have rest from the hard work at the kitchen, laundry and cleaning of the large house and the lot of furniture. On another occasion, he beat me so much with a thick stick that blood started bleeding from my nose and ear, and I left his house..."2 Fardous escapes but Bayumi's and his friends' hands catch her. There, she gets a bed, and Bayumi says to her: "You take the bed and I lie on the floor." aits on her. Thus, Thus, the description of the place describes the character and not the place, which reflects its $\operatorname{tr}^{3}$ her traits constitute a full reflection of what is happening in the place. Therefore, we observe her as a woman who is full of fear, who is unable to feel the beauty of life in any way. Besides, the combination of this space with fear turns it into a terrible prison for both body and soul, and it does not tempt the woman to live in it; on the contrary, it scares her and tempts her to escape from it. This place represents a space of a failing experience and a painful memory and a horizon of writing in which the novelistic makes a dialogue with the autobiographical, even if the writing- self tempts us to think the opposite, due to the existence of more than one common element between the imagined character and the narrating Self that are referred to by more than one textual sign.

The woman in this space appears as a wife and then as a memory but disappears as a body. The partitive vision of space disappears, and in its absence there is absence of the body, too. The Marital House is a harem space from the fundamental perspective, and any exposure to its hidden recesses is considered exposure to the body and an indecent assault against women. Probably this accounts for Nawal al-Sadawi's refusal to keep silent, and her decision to describe it without reluctance and to expose its aspects, and thus, she did not fall into the fundamentalist perspectives that she rejects and rebels against. Thus, while she was generating her novelistic text, she was not affected by the authority of social standards and moral norms, and did not surrender to them while she was drawing the woman/ space and the body/ space, which reflects her infinite awareness of the writing action.

\subsection{Space of the Independent House}

The Independent House represents the space of the woman's outlet. It compensates for the Family House or the Marital House and achieves for the woman her right to practice her existence freely, far from the observation of the family or society and the taboos that they impose on her. In such a place, she achieves the act of writing and lives the rites of love and rites of the body and dreams about the coming future. It also represents the current experience or its memory; the space of the woman's search for balance and harmony with herself and with the other and the external world, after she was unable to achieve that in the space of the Family House or the Marital House.

Fardous has got a house that she owns after she became twenty five years old, after she entered the world of prostitution:" A quarter of a century has passed and I was twenty five when I got a clean house that overlooks the street... clean.. and I possess in my house a large room of bookshelves, where I spend my spare time; and on the walls there are artistic paintings; in the middle there is an expensive frame and within it, there is my secondary school certificate"s to withdraw from the world of prostitution to work at a poor small room after she decide and 4 a company: "after the work ends, I carry my small bag and return home. It was not my home but a small room without a toilet that I rented at an old lady's house... my small salary did not help me to rent except in this house, and in this crowded neighborhood with smithies and plumbing shops."5

We notice Fardous's insistence on mentioning a bookshelf at her house: "I have loved education since I entered school and knew how to read, since I became able to buy books". ${ }^{6}$ Fardous has always loved reading: "I loved reading, and in every book I knew new things... I preferred to read about rulers more than reading about love". ${ }^{7}$ I have always dreamt about a brilliant future: "Sometimes, I imagine that I will be a doctor or an engineer or a lawyer or a judge". ${ }^{8}$ Then we read about her movement to the prison after killing Marzuq to serve her sentence till a death sentence is taken against her. While the house gives a feeling of comfort and security, the prison crates a feeling of fear, stress and depression. The person is sent to jail forcibly if he commits any crime or breaks the law.

All that makes this space a field of a private experience for the writer, which is the basis of her artistic experience. The borders are absent between the boundaries of the Self and the boundaries of writing, which leads to overrunning, debating, and creating the novelistic text that is colored by the shadows of autobiography. And

\footnotetext{
${ }^{1}$ Ibid., p. 16

${ }^{2}$ Ibid., p. 49-53.

${ }^{3}$ Ibid., p. 55

${ }^{4}$ Ibid., p. 77-78

${ }^{5}$ Ibid., p. 83.

${ }^{6}$ Ibid., p. 87

${ }^{7}$ Ibid., p. 31-32.

${ }^{8}$ Ibid., p.30.
} 
when it comes to the house, we notice that the Nawal al-Sadawi is more concerned with its details and parts. The house for her in Woman at a Zero Point looks like a simple place, without significant furniture, which makes it reflect the relationship of passage, emigration and exile that the woman lives waiting to reach the large house. This explains the satisfaction of the main characters/ women in the novels with few necessary pieces of furniture in the hope that they will get the best house, which the main character dreams to have, and where she hopes to find protection, safety and security.

To sum up, we can say that the house in Nawal al-Sadawi's novel does not tempt the characters. Fardous's house, for example, is a 'cold' house that has few pieces of furniture. It consists of a sea-hall, an oven-hall, two mattresses and two pillows: "our house was cold and in winter, my father used to move my mattress and my pillow to the sea-hall and take my place in the oven-hall."The house of her husband Shaeikh Mahmoud was a large ${ }^{1}$ house that consists of a comfortable bed and large furniture that the novel does not describe in detail: "I moved from my uncle's house to Sheikh Mahmoud's house, and thus, I had a comfortable bed instead of the wooden sofa... a large house and a lot of furniture.he has no place and she does not possess In her uncle's house, $\mathrm{s}^{2}$ anything in it, except to sleep on the wooden sofa: "I have no place in this house...except the sofa. A small wooden sofa in the dining room".3

\subsection{The Dialectic of the Space of Streets and Neighborhoods}

The space of the streets and neighborhoods in their openness and expansion is parallel with the space of closed houses and their narrowness: "the neighborhoods and streets are considered typical places of movement and passage. They witness the movement of the characters and constitute a theatre for their going and return when they leave their places of residence or work." 4 These are spaces that are spread in the novelistic discourse.

Nawal al-Sadawi introduces two types of neighborhoods between which there is a relationship of contradiction and exclusion that is far from participation or solidarity, and this carries a symbolical and ideological indication. These are the working-class districts and the high-class districts. The first type is represented in Woman at a Zero Point, but does not have a name. Nawal a-Sadwai does not give these neighborhoods any names, which indicates their marginalization by the authorities. These are neighborhoods that are for daily life of the individuals and are populated by the poor or middle-class groups. These neighborhoods point out the type of living of its residents and the features of their sufferings for the sake of their livelihood and survival. These neighborhoods are characterized by their narrow streets, crowded population and dirtiness, which reflects the social condition of the people who live in them. From this space emerges the ideological attitude of some characters that grow in it, including Fardous, the heroine of the novel. The misery of such places pushes the woman into them to go out to hard work or prostitution.

Thus, the woman's body in these places is associated with humiliation, which finally compels the woman in many cases to leave them once and for all to look for a better life and escape from the pressures of the family observation. This is a risk that the woman does not hesitate to take in order to achieve her freedom and assert herself.

The second type of neighborhoods is the ones that are opposite of the working-class districts: people there have a completely different type of life, thinking and behavior, because "movement from the space of the working class neighborhood to the space of a high class neighborhood entails change of the system of values, and the system of social practices, which we are familiar with to the advantage of a new system that produces new values and new practices". 5 The streets penetrate the spaces of the neighborhoods in order to open onto a journey and adventure. They are narrow, dirty, and crowded in the neighborhoods of the working people but wide, clean and empty in the high class developed neighborhoods. These are the places of luxurious life and free relationships between men and women, absence of observation of inherited norms, customs and traditions in the high-class neighborhoods. In these places, the woman practices her freedom freely, and asserts her existence in her thoughts and movements and actions. She goes to concerts and parties, to the psychiatrist, to conferences and has her own private time to write books and essays. There, we find Sharifa Salah-al-Din and other society ladies.

By that, these neighborhoods can be considered the spaces/ the outlet that achieve for the woman a portion of freedom, and awareness of her entity, her pleasure in her body, and her psychological balance. Thus, we can consider the street as one of the main components of the city, which contribute a lot to clarify the path for Fardous, the central character of the novel Woman at a Zero Point, and reveal the depths of her rebellious soul against her exploitation. The Street as a collective place reflects the people's dynamics in their habitual routine and cracked pleasure. Poverty, need, and shortage of money among the poor and needy classes works on breaking the rhythm

\footnotetext{
${ }^{1}$ Ibid., p. 21

2 Ibid., p. $49-50$.

${ }^{3}$ Ibid., p. $40-41$.

${ }^{4}$ Bahrawi, Hussein (2000) Bunyat al-Shakl al-Riwa'i. p. 79

${ }^{5}$ Ibid., p. 80
} 
of this human familiar dynamics, which devastate the simple man, and consequently, turn the street into a collective grave. Fardous escaped to that place.

In this way, the Place in Nqwal al-Sadawi's novels turns into a dramatic hero that reflects the woman's tragedy, and into a narrative element that achieves the artistic action of communication with the receiver. The Street has become a fate that seizes the focal character, Fardous, in Woman at a Zero Point. It lives with her and in her so that she practices her life and absolute freedom in practicing prostitution. The street does not limit or restrict her freedom of movement or sieges her. It suggests that birth of a prostitution whose life destroyed her and led her to that place. Fardous escapes to the street several times. The first time she escapes when her uncle and his wife decide to get her married to Sheikh Mahmoud:

"I walked in the street as I used to walk every time, except that this time, I was not going to a specific place as I did not know then where I was going. I raised my eyes to the street and felt as if I knew this street for the first time in my life; it was as if another world was opening in front of me that did not exist before, or as if it existed but I did not see it before..."1

The second time is after she escapes from Sheikh Mahmoud's house: "On another time, he beat me with his thick club so much that blood started bleeding from my nose and ear. I left his house and did not go to my uncle's house. I walked along the street with swelling eyes... but no one saw me... the street was wide and crowded that extended endlessly in front of me to the sea. ${ }^{2}$

The third time was after Fardous escapes from Bayumi's house:"... the carpenter came and opened the door and I went out of Bayumi's house running. The street became the safe place that I run to and throw all myself into it... at the end of the day, I found myself in a street that I do not know..." ${ }^{3}$.

The fourth time was after she discovered Ibrahim's betrayal: "... I heard voices in ringing in my ear: he was engaged to the daughter of the Head of the Administrative Council yesterday... I put my hand above my ear to separate between it and the voices; I left the crowded people around him and went out of the door of the company and did not return to my house. I remained in the street; my eyes could not see; my tears were over my face falling and drying... I returned that evening to the company and entered my office; I collected my sheets of paper in my small bag....and when I reached the street, I continued looking behind me as if I was expecting something...It was midnight; the street was quiet... I found myself opening my arms to the magic night and humming with a song that I heard saying:

I have no hope in anything, and do not want anything, and do not fear anything, as I own my freedom. A long luxurious car stopped in front of me. A man looked out of it and I smiled..."4

Fardous started seeing in the street her freedom and emancipation from her fears that have accumulated over the years: "I opened the door and went out to the street; my body was as light as a feather, as if the weight of my body was nothing but accumulation of fear for years over my body." 5

We see that the descriptive units that are related to the street are usually coherently connected to the structure of the narrative. They are employed in an aesthetic way that lent shades and indications to the path of narration and contributed abundantly to the embodiment of the structure of success that is considered the prevailing theme.

We conclude from the above mentioned description that the details of the street (pedestrians, passengers, buses, cars, bus-stops, piles of garbage, the pavement), are employed in a tightly artistic way that contributed to heightening of the dramatic situation of the general action. It also worked on raising the sharpness of the psychological crisis of the heroine and raised her degree of challenge. From this angle, the street in Woman at a Zero Point enters as one of the artistic and objective justifications that convince the receiver of Fardous's and Zena's behavior and their challenges and gasping in their life.

To sum up, the indications that are associated with the neighborhoods and streets vary from one text to the other, and sometimes even within the individual text. These represent the space of harassment of the woman's body by the man and propositioning her to the degree of chasing. This can be illustrated by Fardous's character: "I just saw eyes that were moving towards me in a very slow way.; and I saw them fall on my shoe in a very slow way; and rise in a very slow way over my legs, my hips, my abdomen, my chest, my neck, my lips, and finally they settle in my eyes". ${ }^{6}$ They are the space of hanging out in which the woman finds an outlet, in absence of a direction and an aim. We read: "I walked in the street as I was walking every time, except that this time I was not going to a specific place, and I did not know yet where I was going". 7

\footnotetext{
${ }^{1}$ al-Sadawi, Nawal (1979), p. 47

${ }^{2}$ Ibid., p. $52-53$

${ }^{3}$ Ibid., p. 59

${ }^{4}$ Ibid., p. 93-97.

${ }^{5}$ Ibid., p. 106.

${ }^{6}$ Ibid., p. 48.

${ }^{7}$ Ibid., p. 47
} 


\subsection{Dialectic of the Space of the Prison}

The prison is included in the places of 'house arrest' or 'closed places' or 'hostile places.' As a hostile place, the prison assumes a patriarchal quality in the hierarchical authority inside it because it is compulsory. Reflection on the space of the prison as place that departs from the world of freedom outside the walls, has constituted a fertile material for the novelists in their analysis and impressions that benefit us in understanding the significant function that the prison performs as a novelistic space that is prepared for the stay of the characters during a compulsory stay under strict penalty conditions. In this meaning, the prison constitutes a transition point from the outside into the inside, and from the external world to internal self of the prisoner, including that shift in values and customs, overloading him with heavy obligations and prohibitions. The moment the prisoner steps in the prison, leaving the world of freedom behind him, a series of tortures starts and does not finish until he is set free.

Talking about the prison differs from talking about the house. While he feels safe and secure and comfortable at home, he feels scared, stressed, and depressed in the prison. The person is locked in the prison and is treated with cruelty that is known only to those who have suffered from it. The prison has different qualities from any other place because it is a place where actions of oppression are exerted on people who are against the ruling or occupying or usurping authority. In the prison, the prisoner is deprived of his elementary rights, which is his right of being free.

The place, as Yuri Lotman says, is strongly connected to the concept of freedom, and undoubtedly, the most elementary images of freedom is the freedom of movement. ${ }^{1}$

The space of the prison represents the absented body behind the walls. This space represents 'coercion' and not 'choice', but it participates in the indicative function from the point of view of the relationship of the absented body in the climates of oppression and the boundaries of the prohibited. Concealment of the world of freedom is concealment of the body, and absenting of spaces within the prison, such as the space of visiting, space of recess and space of the cell, are absenting of the details of the body; silence about practices of oppression and alienation upon him transforms action into helplessness, steadfastness into inaction and the will into submissiveness due to the strict conditions of punishment and falling morals. The prison in this meaning constitutes a point of transition from the external into the internal; from dream to the Self due to the change of values, customs, and increase in the obligations and prohibitions. ${ }^{2}$

In the novel Woman at a Zero Point, Fardous is arrested after she kills Marzuq and her telling about that Arab emir, whom she met by accident at the turn of the street in his magnificent car: "and at the turn of the street, I saw a magnificent car from which a head of an excited man emerged. He opened the door of the car and said: "Come with me"... I am an Arab emir... He asked: "Did you kill someone?" I replied: "Yes". He said: "I cannot believe that."... I said: "Perhaps I cannot kill a mosquito, but I can kill a man." ${ }^{3}$

Fardous is imprisoned in a cell that has a door and a window after she was sentenced to death: "there was no bed or a chair or anything that I can sit on in the prison but it has a door and a window". ${ }^{4}$ The prison in this meaning stops to be a place that has dimensions and measurements that characterize its enclosure and limited area. It changes into a special space that rises on the ruins of the external familiar world, which is the source of those changes that the prison imposes on the behavior of its inmates and their way of life when it subjugates them to its special rule." 5

The prison is not a place of geometric dimensions that are distinctive from other places in reality from the point of view of the cruelty of these dimensions, but it becomes a place that reformulates the human being mentally, intellectually and morally. ${ }^{6}$ The topography of the prison appeared through the only window and only door of the cell, and through the emptiness of the cell of anything. Some critics see that walls and windows are among the most prominent topographic landmarks of prisons. The walls in the human prison heritage have a lot of indications, such as: the walls are punishment for crime, and the walls of the prison suggest ancient times, humidity, and the grave, and thus, the prison turns into a place of cruelty and suffering." ${ }^{7}$

Fardous is accused of murdering Marzuq and the police will come to arrest her at a specific hour: "At six o'clock exactly, they will come and take me." 8 In the cell, and after the meeting between Fardous and the psychologist is completed, Fardous starts relating and introducing her life story since her childhood.

In the horizon of this prisonlike law that is covered by a betraying logic, the session with the psychiatrist will appear to be like an oasis in a desert. The relationship of place with its resident is a mutual strong one. The impacts

\footnotetext{
${ }^{1}$ Bahrawi, Hussein (2000), p. 50; Shaheen, Asma (2001), p. 50; Kassed, Salman (2003) Alam al-Nass: Dirasa Bunyawiya fi al-Asalib alSardiya, p. 130-131.

${ }^{2}$ Barradeh, Mohammad (3002). Fadha'at Riwa'iya. Ribat: Ministry of Education. P. 66

${ }^{3}$ Al-Sadawi, Nawal (1979), p. 107-109.

${ }^{4}$ Ibid., p. 13.

${ }^{5}$ Bahrawi (2000), Bunyat al-Shak al-Riwa'i, p. 61

${ }^{6}$ Al-Nabulsi, Shaker (1994), Jamaliyat al-Makan fi al-Riewaya al-'Arabiya. P. 315-31

${ }^{7}$ Ibid., p. 315-316.

${ }^{8}$ Al-Sadawi, Nawal (1979), p. 15.
} 
and features that the place leaves on its resident do not change and cannot be erased easily and quickly."The ${ }^{1}$ importance of the prison lies, especially during the period that the prisoner spends the prisoner inside the prison, in its influence on the life of the prisoner, and the contribution of this stage to changing of the path of his life later on. ${ }^{2}$

The space of the prison is present in the novel of Woman at a Zero Point in order to represent the space that includes a woman (Fardous), who has a feeling of strong anger at life that makes her give up her life. She refuses to continue living and receiving assistance from anyone after she became aware of the truth of men. She resorts to keeping silent and refusing to meet anyone: "She refuses to meet anyone and refuses to reply to anyone. She rarely eats and sleeps at dawn; the female prisoner sees her sometimes sitting but absent-minded staring in the space for several hours.ce and In this way the prisoner's constant helplessness, which results from the shutting of the pla ${ }^{3}$ impossibility of breaking through it, takes place. Fardous continues her way to death and accepts the death sentence and its execution: "... she refuses to answer any question, and she refused to sign the appeal to the President of the State to mitigate the sentence from 'execution' to 'life imprisonment' because the prisoners' impossibility of 4 leaving to the world of house-arrest according to their desire, will create in them a feeling of helplessness due to the absence of every possibility to penetrate this closed space.

The novelistic texts introduce the features of this helpless situation among the prisoners who suffer from shutting of the prison space more than others due to the feelings of humiliation and isolation that overwhelms them.prison space has become a focus for helplessness that lurks for inmate characters and adds up their The ${ }^{5}$ suffering. On the other hand, the prison imposes itself on its inmates in their behavior and subjugates them to its own law.

To sum up, space in its different forms transcends the traditional indication about place, and it changes into an active character in the novel's characters in their present and their future fate. In the events, there is a dramatic escalation and it exerts on the heroine's various kinds of impact that have different degrees of positivity and negativity. Its signs appear in their way of thinking and type of behavior and the manner of their vision about the world.

\section{Summary and Conclusions}

The space of place in of Nawal al-Sadawi's works ranges between two types of places. The first type is characterized by stability while the second type is characterized by mobility. The first type represents houses in their narrowness, in their shutting and in their controls, which accounts for the woman's aversion to them and her tense relationship with them. The prisons represent all the taboos that are imposed on her entity and prevent her from practicing her act of existence freely, away from all types of observation. The body is imprisoned in them and the types of its suppression and types of its sufferings are magnified.

In them, the thought is suppressed, and the word is confiscated. The act of writing is the woman's way to compensate for the forms of her suppression. It is a rebellious reaction that revolts against the practices of alienation and suppression that are practiced on her; it is also a way through which the woman seeks to assert her identity and prove her entity, and achieve her balance in a society that still looks at her as inferior and treats her with suspicion. The second type of spaces is represented by places to which the woman leaves the house/ prisonplaces of shutting, narrowness, tension, and alienation. These include streets, neighborhood café's, pubs, and the sea/the open space.

The streets represent the space of the labyrinth, where the woman dispels some of her anxiety and tension by walking aimlessly. Even in hard climates, these places remain spaces of adventure and awe, where the woman is exposed to varied forms of man's harassments and chasing. The space of the café' and pub remain representatives of intellectual inactivity and indicate some of the woman's loss and marginalization. The woman's penetration of these spaces and her going beyond their prohibited thresholds represent her rebellion against the social norms and moral values in search of a more perfect existence.

The forms of space that Nawal al-Sadawi depicted in her novels reveal the truth of the vision of the woman/ writer/ the Self that narrates the body and her treatment to it when she practices that act of creativity. She speaks about it from behind veils that meet the social perspective that considers the woman's speech about herself, especially her body among the taboos, and the prohibited subjects. By that, she practices in her works about the body and her speech about it, the game of concealment and disclosure, which confirms that she liberated herself from the controls of the environment and the pressures of its values and norms. Probably this game gives the writing of Nawal al-Sadawi its dramatic and aesthetic dimensions, which gains it its particularity, and reveals the

\footnotetext{
${ }^{1}$ Al-Qassem, Nabih (2005). Al-Fan al-Riwa'I Inda Abd al-Rahman Munif: al-Makan. Al-Zaman. Al-Shakhsiya. Kufr Qari': Dar al-Huda li alTiba'a wa al-Nashr. P. 119.

${ }^{2}$ Shaheen, Asma' (2001) Jamaliyat al-Makan fi Riwayat Jabra Ibrahim Jabra. P. 54.

${ }^{3}$ Al-Sadawi, Nawal (1979), p. 5.

${ }^{4}$ Ibid., p. 5-6.

${ }^{5}$ Al-Nabulsi, Shaker (1994). Jamaliyat al-Makan fi al-Riwaya al-'Arabiya. P. 61-62.
} 
truth about the woman's condition in the Arab society, where the heritage continues to practice its presence and impact on the mentality of society, besides the continuity of the domination of man's authority and the shaking of the woman's status in his opinion.

In my view, Nawal al-Sadawi was concerned in her novels with the representation of place through her detained description and exploration of the formal features accurately in a way that also reveals the device of the psychological character and refers to its mood and temper. The writer adopted the element of 'nature' as a frame to embody this psychological condition. Al-Sadawi traces all the elements that constitute the place by a description that introduces the impact of the place on the beholder, and thus, the objects are colored by his view. It is also a description that reflects the writer's point of view.

\section{References}

Abd al-Hamid, Shaker (1988). Dirasa Nafsiya Topologiya. Majallat al-Qahira, Issue 85, p. 65.

Bachelard, Gaston (1980). Jamaliyat al-Makan. Translated by Ghaleb Halsa. Bagdad: Dar al-Jahiz.

Bahrawi, Hussein (1990). Bunyat al-Shakl al-Riwa'i. Beirut: al-Markiz al-Thaqafi al-'Arabi.

Barradeh, Mohammad (2003). Fadha'at Riwa'iya. Ribat: Ministry of Education. P. 66.

Butor, Michel (1969). Essaies Sur Le Rpman, Paris: Gallimard. PP.59-72.

Even, Yosef (1980). Hadmot bi Siporet. Tel Aviv: Sifriyat Poalim. (in Hebrew).

Hamon, Phillippe (2013). Simyulogiat al-Shakhsiyat al-Riwa'iyya. Translated by Sa'id Benkrad. $8^{\text {th }}$. Ed. Latakia. Dar al-Hiwar li al-Nashr wa al-Tawzi'.p. 54.

Hussein, Khaled (2000). Shi'riyat al-Makan fi al-Riwaya al-Jadida. Riyadh: Mu'sasat al-Yaman.

Al-Nabulsi, Shaker (1994). Jamaliyyat al-Makan fi al-Riwaya al-'Arabiyya. Beirut: al-Mu'asasa al-Arabiya li alDirasat wa al-Nashr.

Otham, I'tidal (1998). Ida'at al-Nass fi al-Shi'r al-Arabi al-Hadith. Beirut: Dar al-Hadatha.

Al-Qassem, Nabih (2005). Al-Fan al-Riwa'I Inda Abd al-Rahman Munif: al-Makan. Al-Zaman. Al-Shakhsiya.Kufr Qari': Dar al-Huda li alTiba'a wa al-Nashr. P. 119.

Qassem, Siza (1984). Bina' al-Riwaya. Cairo: al-Hay'ah al-Misriya al-Amma li al-Kitab.

Rasheed, Amina (1998). Tashazzi al-Zaman fi al-Riwaya al-Haditha. Cairo: al-Hay'ah al-Misriya al-'Amma li alKitab.

Al-Sadawi, Nawal (1979). Imra'ah 'Inda Nuqtat al-Sifr. Berut: Dar al-Adab.

Salah, Saleh (2003). Sard al-Akher - Dirasa Buyawiya fi al-Asalib al-Sardiya - Fouad al-Takarli Namuzajan. Dar al-Kindi: Amman.

Salman, Kassed (2003) Alam al-Nass: Dirasa Bunyawiya fi al-Asalib al-Sardiya, Dar al-Kindi: Amman.

Shaheen, Asma' (2001). Jamaliyat al-Makan fi Riwat Jabra Ibrahim Jabra. Beirut: al-Mu'asasa al-'Arabiya. Al-Sharoni, Yosuf (1986). Rihlati Ma' al-Riwaya. Cairo: Dar al-Ma'aref.

Dr Hanan Bishara. is a Palestinian Arab lecturer, scholar, and social activist. She got her Ph.D. degree from the University of Haifa in Arabic Language and Literature. Her thesis is about the Egyptian writer Nawal al-Sa'dawi. The title of her thesis is: "Characterization in Nawal Al-Sadawi's Literary Works from a Gender Point of View: A Diachronic and Synchronic Approach." At present, she works as a lecturer at the Academic Arab College for Education in Haifa.

Dr Bishara is well-known as an intellectual, a scholar and an activist for women's rights in the Palestinian society. Besides, she has published several researches in international journals that deal with the women's status and problems in the Islamic and Arab world. In addition, she has attended several conferences in several countries such as Istanbul (Turkey), Budapest (Hungary), London (UK), Paris (France) and Frankfurt (Germany), where she talked about the conditions of the Arab woman in general. 